$10-8-2021$

\title{
Conceptual framework of the drivers of child marriage: A tool to guide programs and policies
}

\author{
Stephanie Psaki \\ Andrea J. Melnikas \\ Population Council \\ Eashita Haque \\ Population Council \\ Grace Saul \\ Population Council \\ Christina Misunas \\ Population Council
}

See next page for additional authors

Follow this and additional works at: https://knowledgecommons.popcouncil.org/departments_sbsr-pgy

Part of the Family, Life Course, and Society Commons

How does access to this work benefit you? Let us know!

\section{Recommended Citation}

Psaki, Stephanie, Andrea J. Melnikas, Eashita Haque, Grace Saul, Christina Misunas, Sangram Kishor Patel, Thoai Ngo, and Sajeda Amin. 2021. "Conceptual framework of the drivers of child marriage: A tool to guide programs and policies," GIRL Center Research Brief no. 7. New York: Population Council. 


\section{Authors}

Stephanie Psaki, Andrea J. Melnikas, Eashita Haque, Grace Saul, Christina Misunas, Sangram Kishor Patel, Thoai Ngo, and Sajeda Amin 


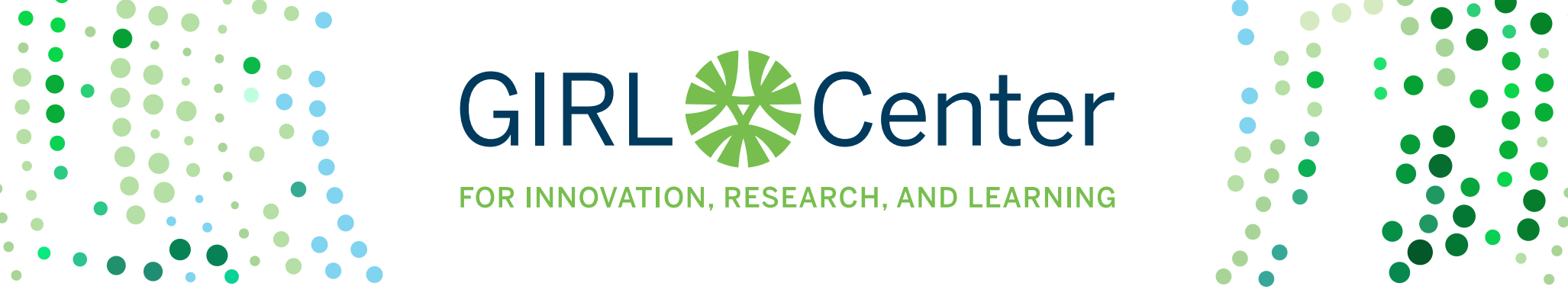

\title{
GIRL Center Research Brief
}

No. 7 October 2021

\section{CONCEPTUAL FRAMEWORK OF THE DRIVERS OF CHILD MARRIAGE: A TOOL TO GUIDE PROGRAMS AND POLICIES}

\author{
STEPHANIE PSAKI, ANDREA J. MELNIKAS, EASHITA HAQUE, GRACE SAUL, \\ CHRISTINA MISUNAS, SANGRAM KISHOR PATEL, THOAI NGÔ, SAJEDA AMIN
}

\begin{abstract}
AT A GLANCE
While there are a number of conceptual frameworks that are useful for understanding the drivers of child marriage and how they interact to perpetuate the practice, there is no simplified and programoriented framework to guide interventions and investments. We present a simplified framework to provide key entry points for understanding which drivers may be most important in particular contexts. Decision-makers such as researchers, donors, and program practitioners can use the framework to help design programs and policies tailored to these contexts.
\end{abstract}

\section{WHY DO WE NEED ANOTHER CONCEPTUAL FRAMEWORK?}

There are several conceptual frameworks to help visualize which factors contribute to the persistence of child marriage. ${ }^{1-5}$ These frameworks share common proposed drivers of child marriage, including poverty, lack of education, and lack of agency in decision-making. While a few studies (e.g., in Ethiopia) and the Girls Not Brides Theory of Change explore the connections between drivers of marriage and common intervention approaches or changing patterns of opportunities for girls, most existing frameworks describe the factors leading to child marriage without explicitly connecting them to the design and implementation of effective interventions. $^{2,3,5}$

Interventions and policies are often designed and implemented without explicit attention to which drivers prevail in each setting due to lack of time, expertise, or data, among other reasons. We offer this framework, which can be adapted based on the drivers in each setting, as a tool to guide decisionmakers in making the most effective investments to address child marriage. Further, this framework can be leveraged by researchers to help guide discussions about the nature of child marriage across settings, and the evidence for which intervention approaches (e.g., empowerment programs vs. cash transfers vs. other) are most likely to be effective in different contexts.

\section{WHAT IS THIS NEW FRAMEWORK?}

We developed a conceptual framework presenting the hypothesized drivers of child marriage that emerged most consistently from a review of the literature (Figure 1). The review included previous conceptual frameworks or theories of change, and expert consultations with researchers, program 
FIGURE 1. CONCEPTUAL FRAMEWORK SHOWING THE HYPOTHESIZED DRIVERS OF CHILD MARRIAGE

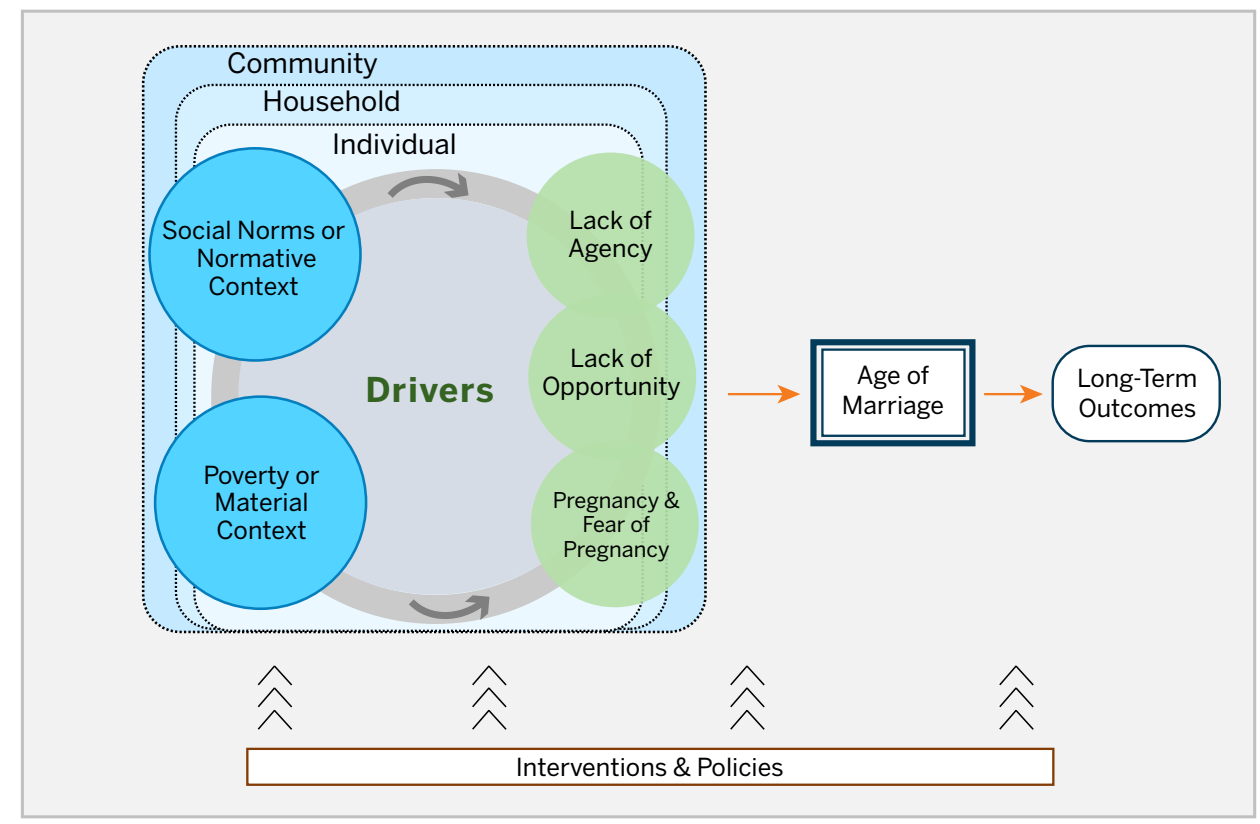

staff, child marriage advocates, and donors working on child marriage. This framework is not "new" in content; rather, it is new in simplicity, presentation and intention as a programmatic tool to guide investment.

We focus on five main drivers in this new framework:

- Social norms and attitudes towards child marriage and roles for women and girls broadly;

- Poverty and economic factors that encourage child marriage as a coping strategy for financial instability, insecurity or as a livelihood strategy for girls;

- Lack of agency among girls to decide when and whom to marry;
A main purpose of this framework is to provide a simple visual that highlights the known main drivers of child marriage and spurs conversations about how programs should work to disrupt these drivers.

- Lack of opportunity for girls and women in education and livelihood alternatives to marriage; and

- Fear of girls' sexuality and pregnancy that drive child marriage as a means to preserve honor or protect against out of wedlock pregnancy that may be associated with shame.

In the figure, Social norms and attitudes and poverty and economic factors are shown as core

Two key frameworks aim to have global relevance in addressing child marriage drivers and possible intervention approaches:

- UNICEF and UNFPA ${ }^{1}$ describe the influence of macro socio-economic factors (e.g. levels of women's empowerment, demographic changes, economic situation) on individual and household-level decisions about marriage and note five strategies to address child marriage: create and expand opportunities for the empowerment of adolescent girls, promote a supportive and gender equal environment, strengthen governance to prevent child marriage, enhance sustainability and impact of child marriage programmes, and build partnerships.

- A theory of change laid out by Girls Not Brides, with input from a range of organizations, presents a broad overview of the vision of a world without child marriage, and describes four programmatic strategies to address child marriage: empowering girls, mobilizing families and communities, providing services, and establishing and implementing laws. ${ }^{2}$ 
distal conditions that in turn drive more proximal factors leading to child marriage. Lack of agency, lack of opportunity, and fear of girls' sexuality and pregnancy reflect community, household, and individual-level factors. The large circle in the middle represents the important connections between these five drivers, which are likely to intersect for many girls and their families.

\section{APPLYING THE FRAMEWORK}

We propose two main ways we see this framework as a useful tool for designing programs and policies:

\section{Stimulate thinking about normative context and underlying power structures}

The framework may be helpful to stimulate thinking and discussions around the normative and economic context in each setting, and how those factors influence what agency and opportunity look like for girls in that context. Similar to recommendations from the Child Marriage Research Network this framework supports thinking about multi-level and intergenerational program approaches that address underlying power structures as part of the social context. ${ }^{6}$

\section{Use in cooperation with available data to decide on which program strategies may be most effective}

We envision that decisionmakers would use this framework in connection with available local data on child marriage and adolescent health. For example, recent survey data, such as those collected by the DHS program, would be useful to understand whether premarital sex is common, and the availability of education and livelihood opportunities for girls and women. Available local qualitative data may provide insight into social norms related to child marriage, as well as insight into girls' agency in decisions about marriage timing. Together, these data could help decisionmakers understand which components may be most important in each setting. They could then look to recent evidence reviews to identify the most effective interventions to address relevant drivers, and to see whether recent evaluations have been conducted in similar contexts.

For example, programs that aim to expand economic opportunities for girls should examine the social context in which economic opportunities exist. In Niger, where child marriage is common and female education enrollment and labor force participation are low, we suggest this requires engaging with families and communities to change perceptions of what roles are acceptable for girls beyond marriage and motherhood and perhaps working on elevating mentors and role models. This approach is similar to the Gender Action Learning System developed by Oxfam, which demonstrated impact on girls' work experience.7.8 In Malawi, this approach may mean addressing livelihood opportunities alongside acknowledging girls' sexuality and agency in sexual partner choice and the role of financial support in romantic relationships because it is a context in which romantic relationships begun in adolescence may drive child marriage. ${ }^{9}$ In Bangladesh, we've learned that community-based programs that focus on skill-building interventions for girls have been successful in delaying marriage as these programs address both aspirations for girls and expectations about marriage among community members, including parents of adolescent girls. ${ }^{10}$ 


\section{CONCLUSION}

While some child marriage frameworks explore the connections between drivers of marriage and common intervention approaches or changing patterns of opportunities for girls, most existing frameworks do not explicitly provide guidance on the design and implementation of effective interventions. We offer this framework, which can be adapted based on the drivers in each setting, as a tool to guide decisionmakers in making the most effective investments to address child marriage.

\section{REFERENCES}

1. United Nations Children's Fund and United Nations Population Fund. Global Programme Phase II Theory of Change. https://www.unicef. org/documents/global-programme-phase-iitheory-change

2. Girls Not Brides. 2014. "Theory of Change on Child Marriage." Cited June 17 2021. https://www. girlsnotbrides.org/articles/theory-change-childmarriage-girls-brides/

3. Jones, N., B. Tefera, G. Emirie, B. Gebre, K. Berhanu, E. Presler-Marshall, et al. 2016. “One size does not fit all: The patterning and drivers of child marriage in Ethiopia's hotspot districts." United Nations Children's Fund and Overseas Development Institute. https://www.unicef.org/ ethiopia/reports/one-size-does-not-fit-all

4. Taylor, A.Y., E. Murphy-Graham, J. Van Horn, B. Vaitla, Á.D. Valle, B. Cislaghi. 2019. "Child Marriages and Unions in Latin America: Understanding the Roles of Agency and Social Norms." Journal of Adolescent Health. Apr 1;64(4):S45-51.

5. Marshall, E.P., M. Lyytikainen, N. Jones, A. Montes, P. Pereznieto, B. Tefera. 2016. "Child marriage in Ethiopia: A review of the evidence and an analysis of the prevalence of child marriage in hotspot districts." United Nations Children's Fund and Overseas Development Institute. https://www. unicef.org/ethiopia/reports/child-marriageethiopia
6. Child Marriage Research Network. 2016. Report: Expert Working Meeting on Sexuality and Child, Early and Forced Marriage (CEFM) [Internet]. Washington, DC: GreeneWorks. Cited June 17, 2021. https://static1.squarespace.com/ static/563ff569e4b07bcd9d94b5b1/t/587e 62e83e00becc5a8a60a3/1484677903798/ CEFMExpertMeetingReport.pdf

7. Reemer, T. and M. Makanza. 2014. Gender Action Learning System - Practical Guide for Transforming Gender and Unequal Power Relations in Value Chains. Oxfam Novib. Cited June 17, 2021. https:// www.oxfamnovib.nl/Redactie/Downloads/English/ publications/150115_Practical\%20guide\%20 GALS\%20summary\%20Phase\%201-2\%20Ir.pdf.

8. Melnikas, A.J., G. Saul, M. Chau, N. Pandey, J. Mkandawire, M. Gueye, A. Diarra, and S. Amin. 2021. "More Than Brides Alliance: Endline Evaluation Report." New York: Population Council.

9. MacPherson, E. 2012. "Fishing, HIV and sex: exploring transactional sex and gender based violence in fishing communities in southern Malawi." Tropical Medicine \& International Health, 17(S1):19-19.

10. Amin, S., J. Saha, J. Ahmed. 2018. “Skills-Building Programs to Reduce Child Marriage in Bangladesh: A Randomized Controlled Trial Journal of Adolescent Health, 63(3): 293 - 300.

\footnotetext{
The Girl Innovation, Research, and Learning (GIRL) Center is a global research center that generates, synthesizes, and translates evidence to transform the lives of adolescent girls. Through rigorous research about what works - and what doesn't - we can better direct limited resources to support evidencebased solutions that improve girls' lives.

popcouncil.org/girlcenter

Recommended citation: Psaki, S., A. J. Melnikas, E. Haque, G. Saul, C. Misunas, S. K. Patel, T. Ngô, S. Amin. 2021. "Conceptual Framework of the Drivers of Child Marriage: A Tool To Guide Programs and Policies." GIRL Center Research Brief No. 7. New York: Population Council.
} 